\title{
Update on Medicinal Plants with Potency on Mycobacterium ulcerans
}

\section{Patrick Valere Tsouh Fokou, ${ }^{1,2}$ Alexander Kwadwo Nyarko,, ${ }^{1,3}$ Regina Appiah-Opong, Lauve Rachel Tchokouaha Yamthe, ${ }^{2,4}$ Mark Ofosuhene, ${ }^{1}$ and Fabrice Fekam Boyom ${ }^{2}$}

\author{
${ }^{1}$ Clinical Pathology Department, Noguchi Memorial Institute for Medical Research, College of Health Sciences, \\ University of Ghana, P.O. Box LG 581, Accra, Ghana \\ ${ }^{2}$ Antimicrobial Agents Unit, Laboratory for Phytobiochemistry and Medicinal Plants Study, Faculty of Science, \\ University of Yaoundé 1, P.O. 812, Yaoundé, Cameroon \\ ${ }^{3}$ Department of Pharmacology and Toxicology, School of Pharmacy, College of Health Sciences, University of Ghana, \\ P.O. Box LG 43, Legon, Ghana \\ ${ }^{4}$ Institute of Medical Research and Medicinal Plants Studies (IMPM), P.O. Box 6163, Yaoundé, Cameroon
}

Correspondence should be addressed to Patrick Valere Tsouh Fokou; tsouh80@yahoo.fr

Received 26 September 2015; Accepted 17 November 2015

Academic Editor: Adair Santos

Copyright (C) 2015 Patrick Valere Tsouh Fokou et al. This is an open access article distributed under the Creative Commons Attribution License, which permits unrestricted use, distribution, and reproduction in any medium, provided the original work is properly cited.

\begin{abstract}
Mycobacterium ulcerans disease has been a serious threat for people living in rural remote areas. Due to poverty or availability of traditional medicine these populations rely on herbal remedies. Currently, data on the anti-Mycobacterium ulcerans activity of plants, so far considered community-based knowledge, have been scientifically confirmed, concomitantly with some medicinal plants used to treat infectious diseases in general. Products derived from plants usually responsible for the biological properties may potentially control Mycobacterium ulcerans disease; numerous studies have aimed to describe the chemical composition of these plant antimicrobials. Thus, the present work provides the first compilation of medicinal plants that demonstrated inhibitory potential on Mycobacterium ulcerans. This work shows that the natural products represent potential alternatives to standard therapies for use as curative medicine for Mycobacterium ulcerans disease.
\end{abstract}

\section{Background}

Mycobacterium ulcerans disease has been a serious threat for people living in rural remote areas. Due to cultural belief, convenience or inaccessibility of modern therapy, in many rural folk, usually relies on traditional medicine for ulcer management [1]. Besides, many people with M. ulcerans disease suffer mutilation and amputation because modern treatment seems to be expensive and also associated with side effects [2]. These traditional medicines are usually sold in markets and public places or administered by traditional healers in their clinics. Most remedies are mixtures of two or more plants species and solvents used including water, palm wine, or oils. Health problems are often treated through self-medication, first with the popular pharmacopoeia $[3,4]$ or specialized pharmacopoeia from traditional healers for difficult health problems.

Traditional treatment for Mycobacterium ulcerans disease is done in four steps that involve diagnosis, necrosis ablation, wound curing, and exorcism [1]. The use of medicinal plants takes place in the second and the third stages of the treatment process [1]. Although medicinal plants may play a significant role in Buruli ulcer case management and control of the disease at an affordable cost for the local population, no attempt has been made to document potent medicinal plants against Buruli ulcer. We previously compiled ethnopharmacological data on plants used traditionally to treat Buruli ulcer which addressed only the activities of ethnopharmacolocally used medicinal plants excluding plants for which there was no report on their use against Buruli ulcer. In this review we 
provide a comprehensive list of medicinal plants that show activity against $M$. ulcerans. The list includes plants that are traditionally used in Buruli ulcer treatment.

\section{An Overview of the Assay Methods Used to Estimate Antimycobacteria Activity}

2.1. Antimicrobial Assays. Several M. ulcerans strains and isolates have been successfully adapted to in vitro culture. They were employed in the activity screening described. Two different assays were used to determine the antimicrobial activity of the extracts, fractions, and pure compounds and where possible were compared to commercially available antimicrobial agents, such as rifampicin ( $\mathrm{MIC}=2 \mu \mathrm{g} / \mathrm{mL})$ [20].

2.1.1. The Proportion Method. The proportion method, which is still the main method used for drug or products screening of Mycobacterium ulcerans by many researchers, applied Löwenstein-Jensen medium. This involved the use of a drug containing media associated with or without dilution of the drug and drug-free media. A standardized inoculum was applied to the drug containing and drug-free media and incubated. After numbering the colonies formed on drug containing medium and on drug-free medium, the MIC was defined as the minimum concentration that inhibited at least 99\% mycobacteria [53]. From the studies reviewed, serial dilution of the plant extracts at concentration ranging from $0.4 \mu \mathrm{g} / \mathrm{mL}$ to $50 \mu \mathrm{g} / \mathrm{mL}$ ( $25 \% \mathrm{vol} / \mathrm{vol}$ to $0.20 \% \mathrm{vol} / \mathrm{vol}$ ) [5] or 0.5 to $50 \mathrm{mg} / \mathrm{mL}[33,43]$ was incorporated into Löwenstein-Jensen media. Thereafter, inocula size of $10^{4}$ to $10^{5}$ mycobacteria/mL was applied and incubated for 8 to 12 weeks at $30-33^{\circ} \mathrm{C}[5,33,43]$.

2.1.2. The Resazurin Microtiter Assays (REMA). Resazurin or alamar Blue-based assays are sensitive and powerful tools used to detect growth inhibition of a given substances in various concentration ranges on mammalian cell lines and microorganism including mycobacteria [66]. The resazurin microtiter assay was first proposed as a simple, rapid, and cheap alternative for Mycobacterium tuberculosis susceptibility testing by Martin et al. [67] and was then adapted by Yemoa et al. in 2011 [21] for Mycobacterium ulcerans susceptibility testing. This method is performed usually in the 96well microplates and can be read with a spectrophotometer or spectrofluorometer or visually without any equipment. In the latter case, which is the one used in the review studies, the minimum inhibitory concentration (MIC) is defined as the lowest concentration of extract that prevents a color change of resazurin from blue to pink. In fact, viable mycobacteria will reduce the blue resazurin into the pink-coloured resorufin. In all cases, extracts or compounds were serially diluted in a 96-well plate and incubate with the inoculum of mycobacteria $10^{5} \mathrm{cfu} / \mathrm{mL}$ in Middlebrook $7 \mathrm{H} 9$ broth supplemented with oleic acid-albumin-dextrose-catalase with concentration ranging from 7.81 to $12,500 \mu \mathrm{g} / \mathrm{mL}$. After 15 days of incubation, resazurin was added and a colour change was visible after additional 48 hours of incubation [11, 21].
2.2. Medicinal Species with Anti-Mycobacterium ulcerans Activities. Several authors have reported medicinal species with biological activity against $M$. ulcerans in vitro. In this work, we have reviewed 33 species either alone or in combination for their potential on M. ulcerans in vitro (Table 1).

2.2.1. Aloe vera (L.) Burm.f. A. vera is an evergreen perennial medicinal plant known for centuries for its beauty and medicinal and skin care properties [51]. Classically, A. vera has been used for its wound healing potential [51]. Recently Seefeld et al. [68] reported its use in the traditional treatment of Buruli ulcer while Addo et al. [5] have demonstrated its in vitro activities on 7 different $M$. ulcerans strains and isolates with MIC mean value of $40 \mu \mathrm{g} / \mathrm{mL}$ (Table 1 ). Phenolic compounds such as chromone, anthrone, anthraquinone [52], aloin, and emodin have been identified and are known for their antibacterials effect [51]. Also, its anti-inflammatory action through the inhibition of the cyclooxygenase pathway and reduction of prostaglandin E2 production from arachidonic acid was reported. Recently, the novel antiinflammatory compound called C-glucosyl chromone was isolated from gel extracts [51] of $A$. vera. The anti-inflammatory activity combined with the antibacterial effect and the wound healing activity of $A$. vera support its use in Buruli ulcer case management. In fact, its high water content can keep the wound moist and increase epithelial cell migration. In addition, its content of glucomannan, a mannose-rich polysaccharide, and gibberellin, a growth hormone, interacts with growth factor receptors on fibroblasts and macrophages, thereby significantly increasing collagen and proteoglycan synthesis, and the degree of collagen cross linking after topical and oral administration resulting in accelerated tissue repair $[51,52]$. Furthermore, acemannan, saponin, and genin isolated from Aloe leaves have been shown to accelerate wound healing $[52,69,70]$.

2.2.2. Alstonia boonei De Wild. Alstonia boonei is a large deciduous evergreen tree, usually up to $45 \mathrm{~m}$ tall and $1.2 \mathrm{~m}$ in diameter, and is also called devil tree in tropical and subtropical Africa, Central America, and Australia [71]. The plant is used to treat various diseases across Africa and the stem bark has been listed as an agent useful for treatment of ulcer or wounds [72]. Addo et al. [5] reported in vitro activity of infusion of leaves on $7 \mathrm{M}$. ulcerans strains and isolates with MIC mean value of $40 \mu \mathrm{g} / \mathrm{mL}$ (Table 1 ). A wide array of chemical compounds, including alkaloids (echitamine, echitamidine, voacangine, akuammidine, $\mathrm{N}$-formylechitamidine, $\mathrm{N} \alpha$-formyl-12-methoxyechitamidine), tannins, iridoids (boonein, loganin), steroids, saponins, glycosides, flavonoids, and terpenoids and triterpenoids (lupeol, ursolic acid, and $\beta$-amyrin) $[19,71-73]$, have been isolated from the plant that might support its reported Mycobacterium ulcerans inhibitory effects.

2.2.3. Pupalia lappacea Juss. Pupalia lappacea is a widespread medicinal plant found in savannah and woodland localities 


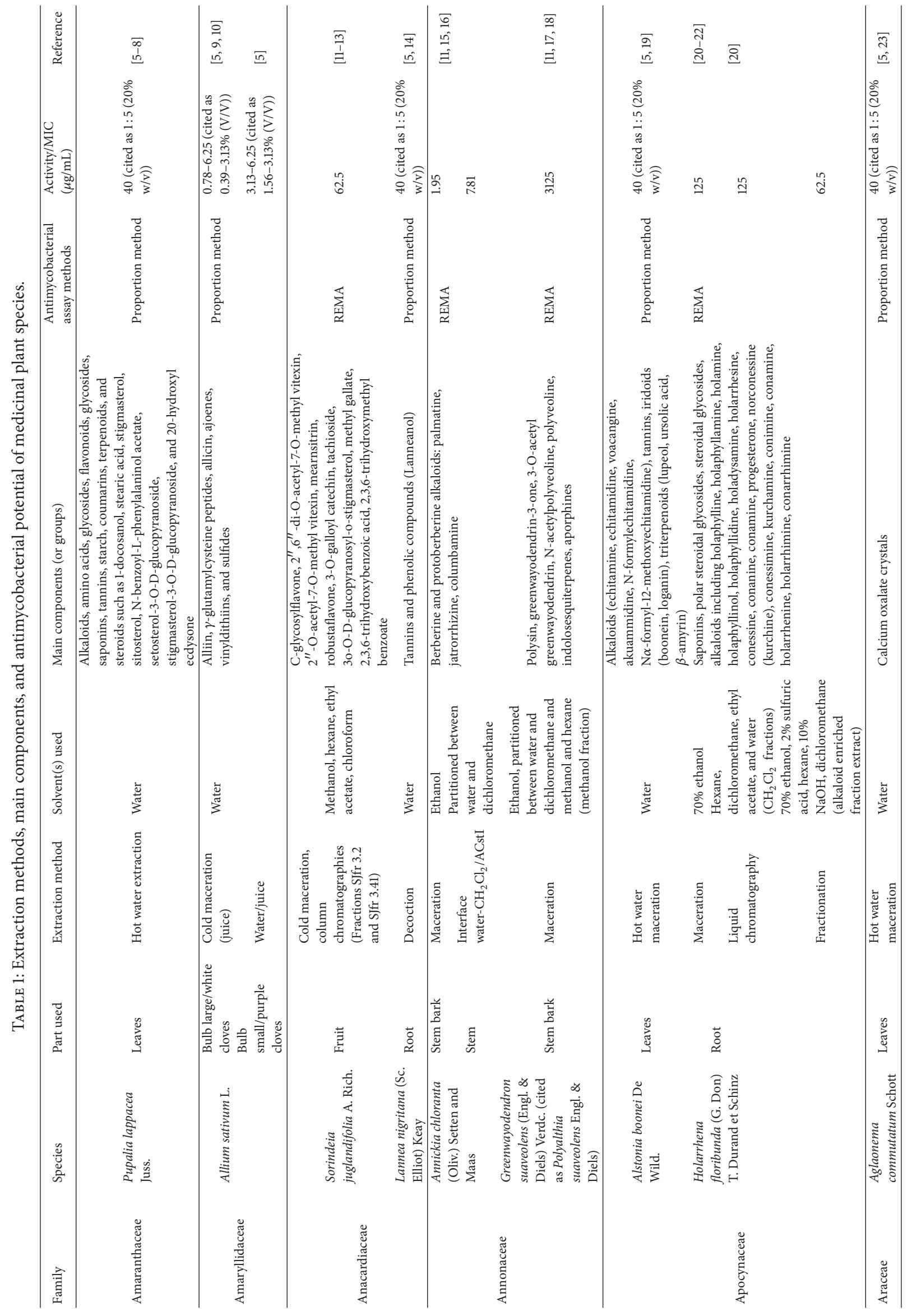




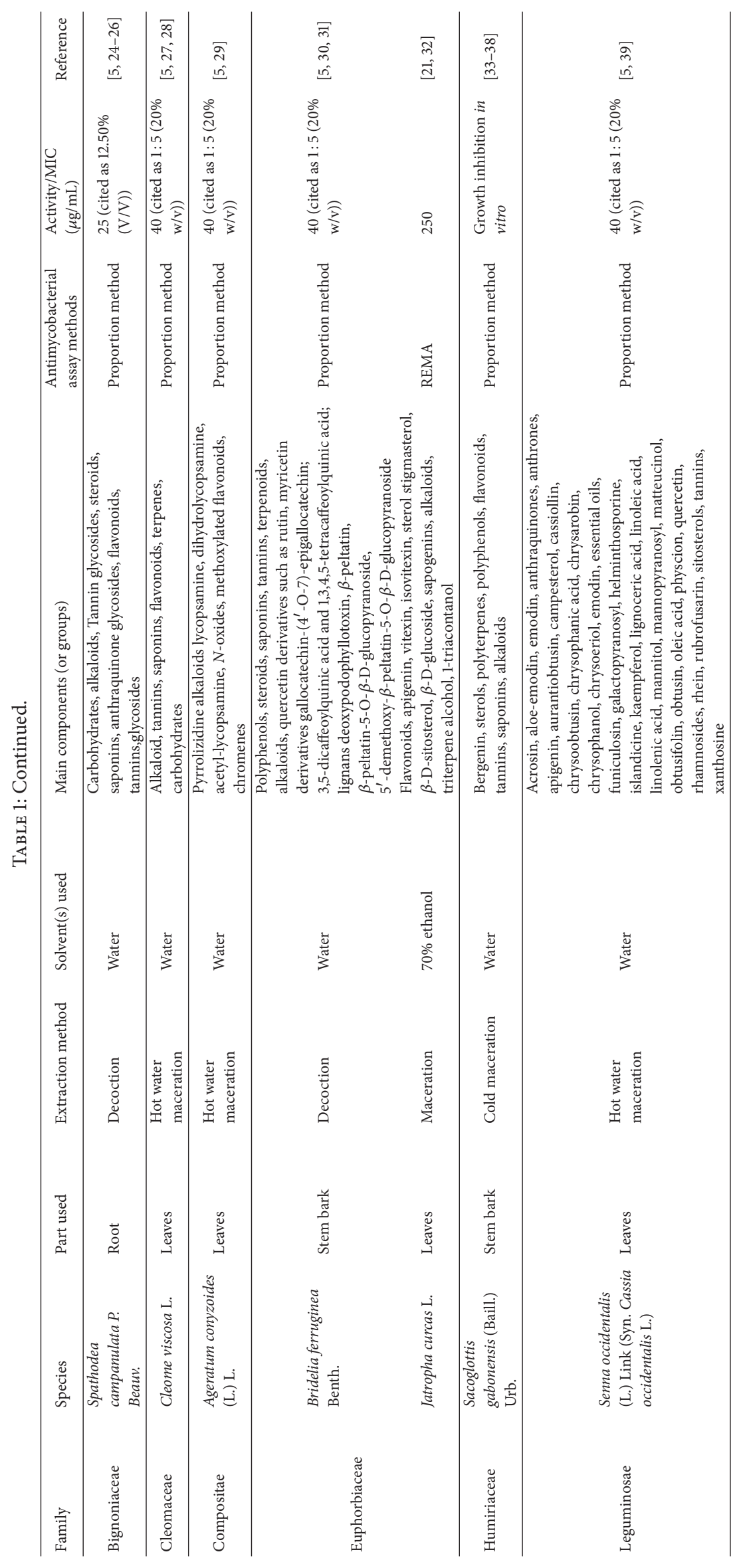




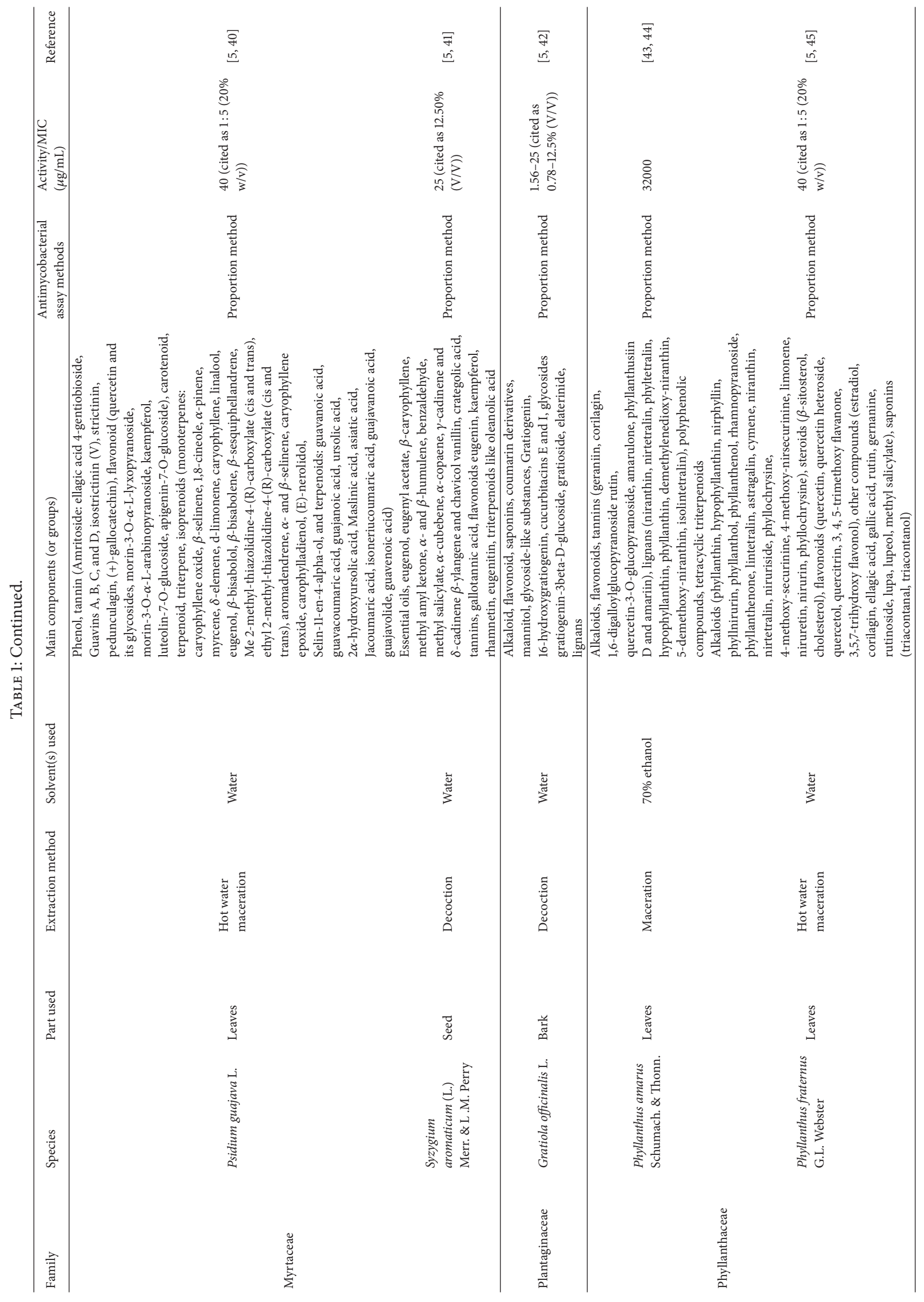




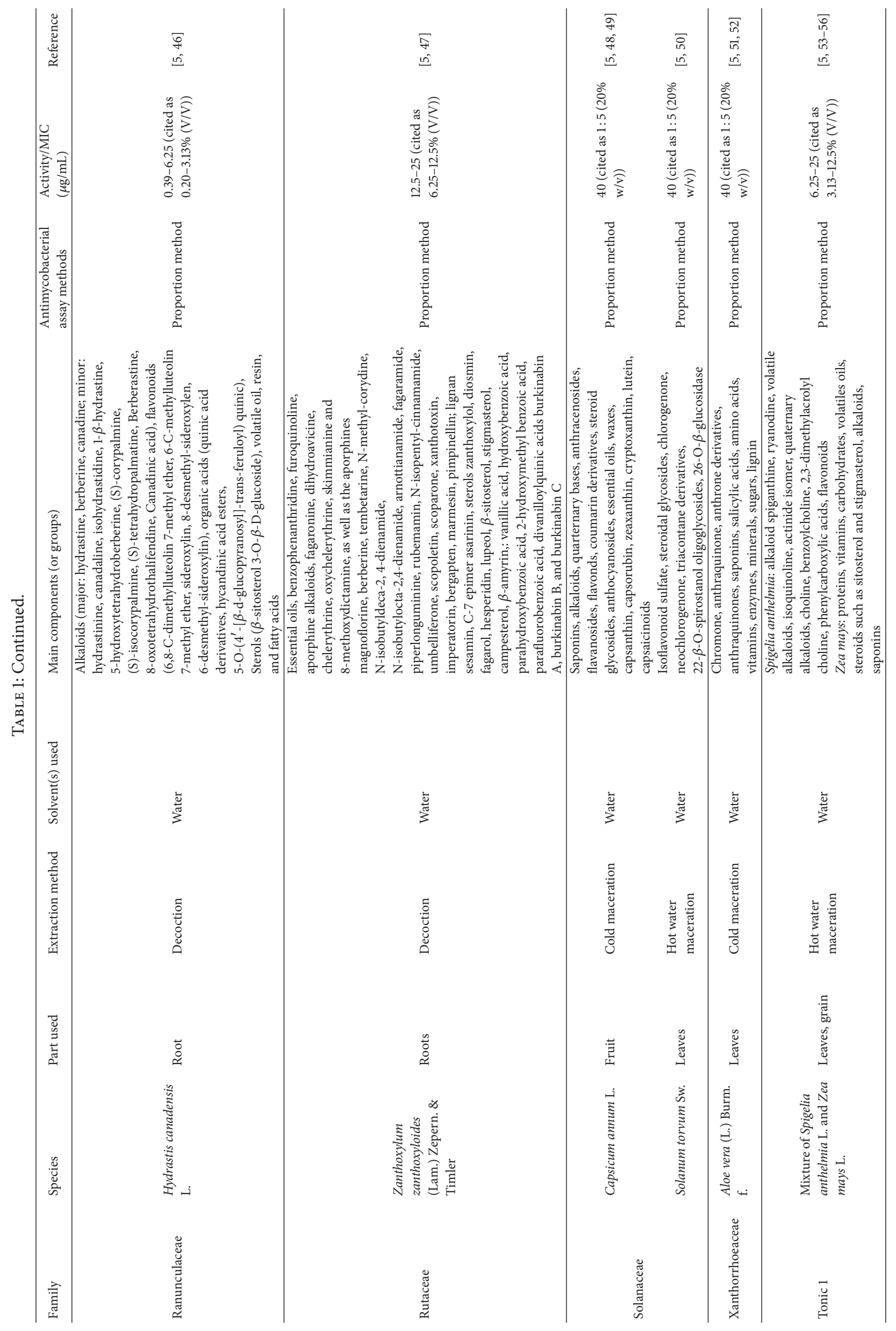




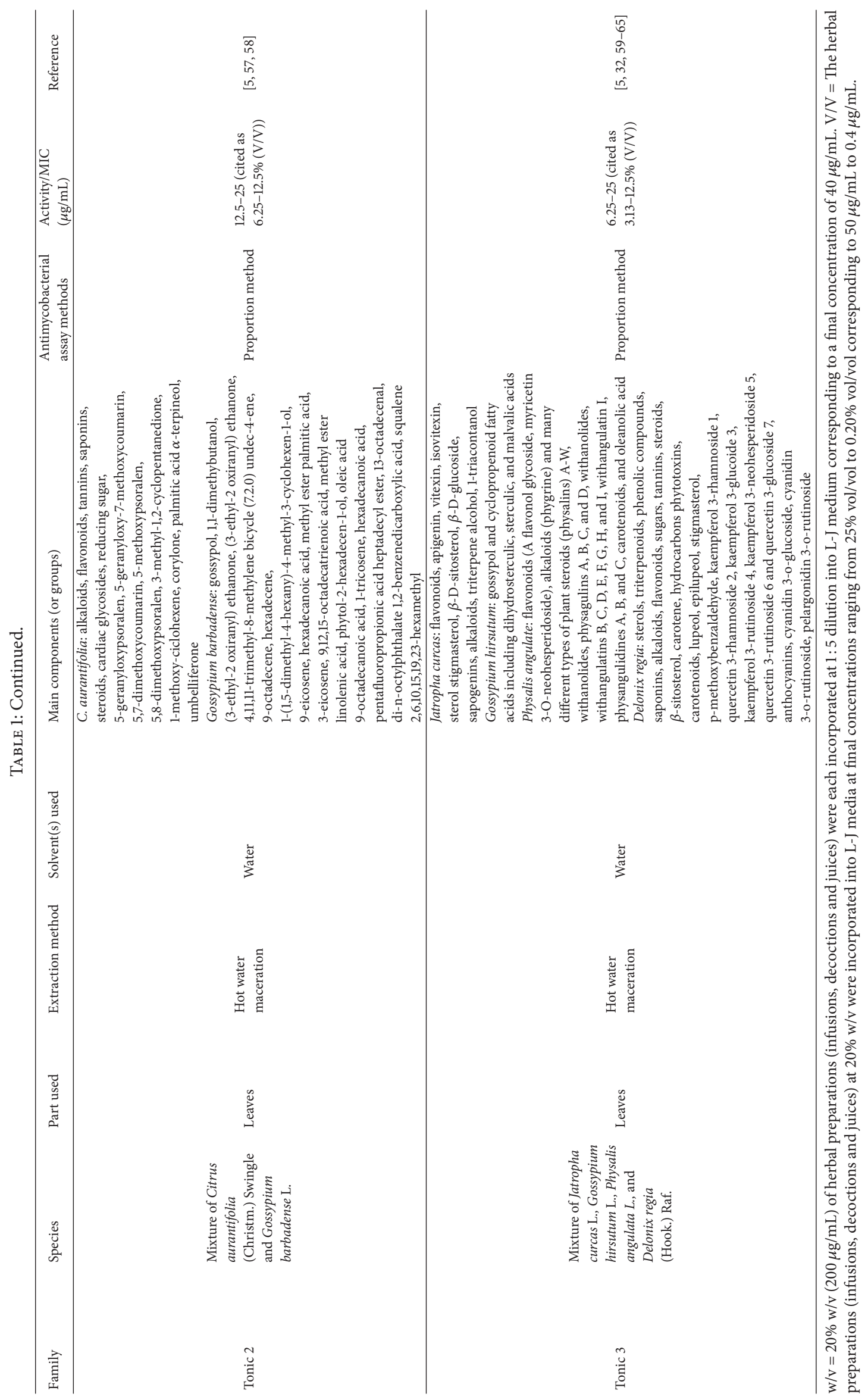


as well as forests in tropical Africa and in Asia [74]. It has been used in the management of wound $[5,6]$ and its leaves extracts have shown inhibitory activity on $7 \mathrm{M}$. ulcerans strains and isolates with MIC mean value of $40 \mu \mathrm{g} / \mathrm{mL}$ (cited as 1:5 (20\% w/v)) (Table 1) [1]. Chemical investigations show that $P$. lappacea leaf extract contains alkaloids, glycosides, flavonoids, saponins, tannins, coumarins, terpenoids, and steroids such as 1-docosanol, stearic acid, stigmasterol, sitosterol, N-benzoyl-L-phenylalaninol acetate, setosterol-3-O-Dglucopyranoside, stigmasterol-3-O-D-glucopyranoside, and 20 -hydroxyl ecdysone. These compounds have been shown to promote the wound healing process in animals and humans. Stigmasterol found in the plant has been shown to exhibit haemostatic and anti-inflammatory activities. Similarly, 20hydroxyl ecdysyne also present in the plant promotes protein synthesis and wound healing in animals and humans. Since some of the compounds contained in P. lappacea leaves extract have antibacterial activities and also promote the wound healing process, the plant extract may exhibit wound healing activities as claimed by the traditional practitioners [6-8].

\subsubsection{Lannea nigritana (Sc. Elliot) Keay. Lannea nigritana} is a small tree of 3-6 m of height found in the tropical rain forest [14]. It is used in traditional medicine for the treatment of various infectious diseases [14] including wounds [5]. The leaves of the plant showed activity on $7 \mathrm{M}$. ulcerans strains and isolates with MIC mean values of $40 \mu \mathrm{g} / \mathrm{mL}$. Phytochemical studies on this plant are scanty. Meanwhile the plant is known to contain tannins and phenolic compounds (Lanneanol) [5].

\subsubsection{Aglaonema commutatum Schott. Aglaonema commu-} tatum is a common ornamental plant used to treat $\mathrm{BU}$ that showed MIC mean value of $40 \mu \mathrm{g} / \mathrm{mL}$ on $7 M$. ulcerans isolates (Table 1) [5]. Besides, solution from washings of leaves showed inhibitory effects on growth of bacteria such as E. coli, $P$. aeruginosa, and $S$. aureus [75] which are commonly involved in wound infection. All parts of the plant contain the active constituent calcium oxalate crystals [23].

\subsubsection{Ageratum conyzoides (L.) L. Ageratum conyzoides} is an annual herbaceous plant used in African traditional medicine for the treatment of wounds, burns, and ulcer [76]. Addo et al. [5] demonstrated the leaves activity on 7 $M$. ulcerans strains and isolates with MIC mean value of $40 \mu \mathrm{g} / \mathrm{mL}$ (Table 1). A. conyzoides contains phenolic compounds, methoxylated flavonoids and chromenes, and pyrrolizidine alkaloids, pyrrolizidine alkaloids lycopsamine, dihydrolycopsamine, and acetyl-lycopsamine, and their $\mathrm{N}$ oxides [29].

2.2.7. Cleome viscosa L. Cleome viscosa is commonly known as tickweed, wild mustard, or spider plant that occurs in woodland and grassland. It is a weed found in fallow land, fields, roadsides, and wasteland. It often grows on sandy soils but sometimes grows on calcareous and rocky soils. It is a widely distributed herb with yellow flowers and long slender pods containing seeds [77]. The leaves and whole plant of
C. viscosa are used as a folk remedy to cure wounds, ulcers, inflammations, and skin infections [27]. Its leaves have shown MIC mean value of $40 \mu \mathrm{g} / \mathrm{mL}$ (cited as 1:5(20\% w/v)) on $7 \mathrm{M}$. ulcerans isolates (Table 1) [5]. Methanolic extract of the aerial parts of the plant is also reported to have significant wound healing properties on experimentally induced excision and incision wound models in rats in addition to its previously reported analgesic, antimicrobial, and antiulcer activities [77]. All of this supports the traditional use of the plant. Its content of alkaloids, tannins, saponins, flavonoids, terpenes, and carbohydrates $[27,28]$ may be probably responsible for the observed wound healing activity.

\subsubsection{Phyllanthus fraternus G. L. Webster. Phyllanthus frater-} nus commonly is a small, erect, annual herb that grows $30-$ $40 \mathrm{~cm}$ in height [78] indigenous to the rainforests of the Amazon and other tropical areas throughout the world [79]. The plant has numerous uses by indigenous peoples to treat blennorrhagia, colic, diabetes, dysentery, fever, flu, tumors, jaundice, vaginitis, dyspepsia, and pain [80]. P. fraternus has previously demonstrated an MIC mean value of $40 \mu \mathrm{g} / \mathrm{mL}$ (cited as 1:5 (20\% w/v)) on 7 M. ulcerans (Table 1) [5] isolates and strains. It has been shown to contain alkaloids, steroids, glycosides, tannins, saponin, flavonoids, other compounds (estradiol, corilagin, ellagic acid, gallic acid, rutin, gernanine, rutinoside, lupa, lupeol, and methyl salicylate), and saponins (triacontanal, triacontanol) $[45,79]$. The reported antimicrobial activity may be attributed to the presence of some of the reported secondary metabolites. However, the active compound(s) known to give this observed activity need to be identified.

\subsubsection{Bridelia ferruginea Benth. Bridelia ferruginea Benth. is} a gnarled shrub which can reach the sizes of a tree in suitable condition [30]. B. ferruginea bark is used for treatment of bacterial infections on wound [81] and has been shown to inhibit the growth of $7 \mathrm{M}$. ulcerans strains and isolates with an MIC mean value of $40 \mu \mathrm{g} / \mathrm{mL}$ (cited as 1:5 (20\% w/v)) (Table 1) [5]. The presence of phytochemical such as polyphenols, steroids, saponins, tannins, terpenoids, and alkaloids $[30,31]$ may support the demonstrated antimicrobial activity against mycobacteria.

2.2.10. Senna occidentalis (L.) Link. Senna occidentalis (syn. Cassia occidentalis) is an annual or perennial plant [39] that has been used as natural medicine in rainforests and tropical regions as laxative, analgesic, febrifuge, diuretic, hepatoprotective, vermifuge, and cholagogue [82]. Leaf paste is externally applied for wound healing [39]. S. occidentalis leaf extracts were found to be active against different microbes [39] and inhibit the growth of $7 \mathrm{M}$. ulcerans strains and isolates with MIC mean value of $40 \mu \mathrm{g} / \mathrm{mL}$ (cited as 1:5 $(20 \% \mathrm{w} / \mathrm{v}))$ (Table 1) [5]. The presence of compounds such as acrosin, aloe-emodin, emodin, anthraquinones, anthrones, sitosterols, tannins, and xanthosine [39] can justify its reported antimycobacterial activity. 
2.2.11. Psidium guajava L. Psidium guajava, commonly known as guava, is a native plant of tropical America and has been used in indigenous system of medicine for the treatment of various human ailments such as wounds, ulcers, bowels, and cholera [40, 83]. In Central and West Africa, its decoctions are used externally for skin ulcers [84]. P. guajava also possesses antibacterial and anti-inflammatory properties and also inhibited the growth of $7 \mathrm{M}$. ulcerans strains and isolates with MIC mean value of $40 \mu \mathrm{g} / \mathrm{mL}$ (cited as $1: 5(20 \% \mathrm{w} / \mathrm{v})$ ) (Table 1) [5]. A number of secondary metabolites in good yield have been isolated and some, which are mainly phenolic, flavonoid, carotenoid, volatile oil, tannins, terpenoid, and triterpene, have been shown to possess useful biological activities [40].

2.2.12. Capsicum annum L. Capsicum annum is a perennial shrub, with woody trunk, which bears green fruits that ripen to red. The active ingredient in the plant is capsaicin that is used for the management of various medical conditions [48]. This plant possesses antibacterial and wound healing properties. It is used often in combination with Pothos scandens L. and Allium sativum to heal wounds [85]. The maceration of fruit, used to treat Buruli ulcer, has showed MIC mean value of $40 \mu \mathrm{g} / \mathrm{mL}$ (cited as 1:5 (20\% w/v)) on 7 M. ulcerans strains and isolates (Table 1) [5]. Bioactive chemical compounds against bacteria involved in wound infection found in C. Annum included saponins, alkaloids, quaternary bases, anthracenosides, flavanosides, flavonds, coumarin derivatives, steroid glycosides, anthocyanosides, essential oils, waxes, coloured materials (mainly capsanthin, capsorubin, zeaxanthin, cryptoxanthin, and lutein), and several capsaicinoids $[48,49]$.

2.2.13. Solanum torvum Sw. Solanum torvum, commonly known as Turkey berry, is an erect spiny shrub about $4 \mathrm{~m}$ tall, evergreen and widely branched found in Africa and West Indies. The fruits and leaves are widely used in Cameroonian folk medicine. Agrawal et al. [86] have reported the traditional use of this plant as an antiulcer agent while its antimicrobial properties of the leaves are known and are used to manage cuts and wounds [87]. Its leaf decoction inhibits the growth of $7 \mathrm{M}$. ulcerans strains and isolate with MIC mean value of $40 \mu \mathrm{g} / \mathrm{mL}$ (cited as 1:5 (20\% w/v)) (Table 1) [5].S. torvum contains a number of potentially pharmacologically active chemicals like stigmasterol involved in the wound healing process and isoflavonoid sulfate and steroidal glycosides, chlorogenone and neochlorogenone, triacontane derivatives, $22-\beta$-O-spirostanol oligoglycosides, $26-\mathrm{O}-\beta$-glucosidase, tetratriacontanoic acid, sitosterol, stigmasterol, campesterol, and C-22 steroidal lactone saponins $[50,86]$.

2.2.14. Spathodea campanulata P. Beauv. Spathodea campanulata is a tree that grows between 7 and 25 meters (2382 feet) tall. It is native to tropical Africa and Southern Asia. S. campanulata flowers and bark are used traditionally in the treatment of mental disorders, malaria, hemorrhoids, bacterial infections, HIV, poor blood circulation, gastrointestinal diseases, respiratory ailments, and genital-urinary system disorders [24] as well as relief for skin conditions, swollen cheeks, and body rashes and Buruli ulcer. The leaves and stem bark paste are used to bandage ulcers while infusions of the leaves, root, and bark are also used to clean ulcers $[4,5,20,88,89]$. The decoction of the root showed inhibitory activity on $7 \mathrm{M}$. Ulcerans strains isolates with MIC mean value of $25 \mu \mathrm{g} / \mathrm{mL}$ (cited as $12.50 \%$ (V/V)) (Table 1) [5]. Biologically active phytochemicals have been identified such as alkaloids, tannins, saponins, glycosides, anthraquinone glycosides, steroids, flavonoids, tannins, and glycosides [2426].

2.2.15. Allium sativum L. Allium sativum has been widely recognized as a valuable spice and a popular remedy for various ailments and physiological disorders. The plant appears to have originated from Central Asia and then spread to China, the Near East, and the Mediterranean region before moving west to Central and Southern Europe, Northern Africa, and Mexico [90]. The juice of $A$. sativum cloves is used to treat Buruli ulcer conditions [5]. It has been shown experimentally to accelerate the wound healing process in mice [91]. Besides, aqueous extract of $A$. sativum in combination with honey has shown acceleration of wound healing in rats [92]. It has shown growth inhibition on $7 \mathrm{M}$. ulcerans strains and isolates with MIC mean values of $0.78-6.25 \mu \mathrm{g} / \mathrm{mL}$ (cited as $0.39-$ $3.13 \%(\mathrm{~V} / \mathrm{V})$ ) (Table 1) [5]. Active constituents such as alliin, allicin and $\gamma$-glutamylcysteine, ajoenes, and vinyldithiins have been identified $[9,10]$. Allicin has antimicrobial effects against many bacteria and fungi [90] usually found in ulcers. Its activity on $M$. ulcerans combined with its antibacterial, antifungal and anti-inflammatory, antioxidant, [90, 93], and wound healing potency supports its traditional use in Buruli ulcer treatment.

2.2.16. Syzygium aromaticum (L.) Merr. \& L. M. Perry. Syzygium aromaticum is an evergreen tree found worldwide [41]. It is a natural analgesic and antiseptic used primarily in dentistry because of its main ingredient eugenol. It has been traditionally used externally or locally for the treatment of minor infections of the mouth and skin, dressing of minor wounds, and Buruli ulcer [5]. Its seeds have showed MIC mean value of $25 \mu \mathrm{g} / \mathrm{mL}$ (cited as $12.50 \%$ (V/V)) on 7 M. ulcerans isolates (Table 1) [5]. Many active ingredients have been identified from S. aromaticum including essential oils, tannins, gallotannic acid, methyl salicylate, flavonoids eugenin, and triterpenoids like oleanolic acid [41].

2.2.17. Hydrastis canadensis L. Hydrastis canadensis is an herbaceous perennial growing short yellowish rhizome [94]. $H$. canadensis is widely used to treat many ailments, including arrow wounds [46]. It inhibited the growth of $7 \mathrm{M}$. ulcerans strains and isolates with MIC values of $0.39-6.25 \mu \mathrm{g} / \mathrm{mL}$ (cited as $0.20-3.13 \%(\mathrm{~V} / \mathrm{V})$ ) on (Table 1) [5]. In an antimicrobial screening program, $H$. canadensis extract also exhibited significant activity against multiple drug resistant strains of M. tuberculosis and other Mycobacterium species as well as other human pathogens [95]. H. canadensis is found 
to contain alkaloids, flavonoids, organic acids, sterols $(\beta$ sitosterol 3-O- $\beta$-D-glucoside), volatile oil, resin, and fatty acids [46]. Bioassay-guided fractionation revealed berberine to be the active constituent on mycobacteria [95]. This in combination with its wound healing properties can explain the higher activity observed against $M$. ulcerans and support the indigenous treatment of Buruli ulcer.

\subsubsection{Zanthoxylum zanthoxyloides (Lam.) Zepern. \& Timler.} Zanthoxylum zanthoxyloides is widely distributed in many African countries. It is well known for its use in treating elephantiasis, toothache, sexual impotence, gonorrhoea, malaria, dysmenorrhoea abdominal pain [96], and Buruli ulcer [5]. It showed inhibitory activity with MIC values $12.5-$ $25-\mu \mathrm{g} / \mathrm{mL}$ (cited as $6.25-12.5 \%(\mathrm{~V} / \mathrm{V})$ ) on $7 \mathrm{M}$. ulcerans strains and isolates (Table 1) [5] in addition to its antimicrobial activity $[5,96]$. Antibacterial and anti-inflammatory amides have also been isolated from the plant [96] as well. The presence of a diversity of essential oils, alkaloids, and several aliphatic and aromatic amides [47] strengthens claims of effectiveness of this plant in its traditional use for treatment of Buruli ulcer.

2.2.19. Gratiola officinalis L. Gratiola officinalis Linn. is a glabrous perennial herb and is native to the south of Europe, and its favourable habitat is damp grounds. Gratiola officinalis L., commonly known as common Hedgehyssop or "Herb of Grace" is well known for its pharmacological properties. Various parts of this plant (root and herb) are used in phytomedicines to treat skin diseases [42]. This may explain the observed good inhibitory activity on $7 \mathrm{M}$. ulcerans strains and isolates with MIC values $1.56-25-\mu \mathrm{g} / \mathrm{mL}$ (cited as $0.78-12.5 \%(\mathrm{~V} / \mathrm{V})$ ) (Table 1) [5]. The active constituents found in G. officinalis include gratiogenin, 16-hydroxygratiogenin, cucurbitacins $\mathrm{E}$ and I, glycosides gratiogenin-3beta-D-glucoside, gratioside, elaterinide, flavonoids, alkaloids, lignans, coumarin, and saponins which have many biological properties [42].

2.2.20. Jatropha curcas L. Jatropha curcas Linn belonging to the family Euphorbiaceae is a drought-resistant shrub originating in Central and South America but now thrives in many parts of the tropics and subtropics in Africa and Asia [97]. J. curcas has been used as traditional medicine to cure Buruli ulcer [4]. Its leaf ethanolic extract inhibited the growth of M. ulcerans ATCC 19423 with MIC value of $250 \mu \mathrm{g} / \mathrm{mL}$ and the crude bark extract of Jatropha curcas has been shown to be very effective in accelerating wound healing process in rat [98]. Researchers have isolated and characterized a number of biologically active constituents such as flavonoids, apigenin, vitexin, isovitexin, stigmasterol, $\beta$-D-sitosterol, $\beta$ D-glucoside, sapogenins, alkaloids, triterpene alcohol, and 1triacontanols from all parts of this plant [32].

2.2.21. Holarrhena floribunda (G. Don) T. Durand. Holarrhena floribunda grows as a shrub or tree up to $25 \mathrm{~m}$ tall, with a stem diameter of up to $30 \mathrm{~cm}[4,21]$. Bark is used as an enema or in baths to treat skin infections and the leaf sap is sprinkled on wounds as a haemostatic. A sap extracted from its leaves is sprinkled onto wounds to act as a haemostatic [22]. Yemoa et al. [4] report its use in the traditional treatment of Buruli ulcer and hydroethanolic extract and $\mathrm{CH}_{2} \mathrm{Cl}_{2}$ fraction of root inhibited the growth of $M$. ulcerans ATCC 19423 with MIC value of $125 \mu \mathrm{g} / \mathrm{mL}$ [20] while that of the alkaloid enriched fraction had an MIC of $62.5 \mu \mathrm{g} / \mathrm{mL}$. These give some support to the use of this plant in traditional medicine (Table 1) [21]. It contains active compounds such as saponins, polar steroidal glycosides, steroidal glycosides, and alkaloids including holaphylline, holaphyllamine, holamine, holaphyllinol, holaphyllidine, holadysamine, holarrhesine, conessine, and progesterone $[21,22]$.

2.2.22. Sorindeia juglandifolia (A. Rich.) Planch. ex Oliv. Sorindeia juglandifolia is a shrub or small tree that grows to $23 \mathrm{~m}$ tall and $40 \mathrm{~cm}$ in diameter. It is widespread in the West and Central Africa subregion. This plant is found on the edges of dry deciduous forest and regrowth in humid forest and in the galleried Sudanian forest of Senegal to Dahomey and also in Ubangi-Shari, Angola, and Zambia. Its common English name is "damson" [99, 100]. In Senegal pulped leaves are applied to sores and ulcers [101]. Fruit fractions and a purified compound (2,3,6-trihydroxymethyl benzoate) from $S$. juglandifolia is reported to have an antimycobacterial activity against $M$. ulcerans strain 1615 with MIC value of $62.5 \mu \mathrm{g} / \mathrm{mL}$ and minimal bactericidal concentration (MBC) values of 250 and $125 \mu \mathrm{g} / \mathrm{mL}$, respectively [11].

\subsubsection{Annickia chlorantha (Oliv.) Setten \& Maas. Annickia} chlorantha is a tree up to $30 \mathrm{~m}$ tall commonly known as "Yello Wood" found in dense forests in Cameroon, Nigeria, and Gabon. In the southern forest zone of Cameroon, it is used for the traditional treatment of stomach problems, jaundice, urinary tract infections, malaria, tuberculosis, hepatitis, and some forms of ulcer $[3,15]$. The stem bark and stem preparations of $A$. chlorantha have been shown to have high inhibition against the growth of M. ulcerans strain 1615 with respective MIC values of 1.95 and $7.81 \mu \mathrm{g} / \mathrm{mL}$ (Table 1). The chemistry of $A$. chlorantha formally Enantia chlorantha has been extensively studied. Berberine and protoberberine alkaloids [15] with antibacterial [102] properties have been isolated from the stem bark of A. chloranta. A mixture of protoberberine alkaloids from $A$. chlorantha containing palmatine, jatrorrhizine, and columbamine was shown to prevent liver injury from chemically induced traumatization and also promoted the healing process after injury in experimental mice [16].

2.2.24. Greenwayodendron suaveolens (Engl. \& Diels) Verdc. Greenwayodendron suaveolens is a deciduous, medium-sized to fairly large tree up to 35 (to 45) $\mathrm{m}$ tall that is widespread from Southern Nigeria, East to Western Uganda, Northern Tanzania, and Southern Democratic Republic of Congo and Cabinda (Angola) and commonly known in English as "Molinda." Various plant parts are used in traditional 
medicine to treat stomach ache and other pains, gonorrhoea, psychosis, rheumatism, epilepsy and toothache, malaria, liver complaints and headache, helminths, oedema and swollen glands, and hepatitis; it is used to manage infertility, as diuretic, purgative, an aphrodisiac, and to facilitate childbirth [17]. Extracts and fractions from G. Suaveolens (cited as Polyalthia suaveolens) have been shown to inhibit $M$. ulcerans with moderate MIC and MBC values of 3,125 $\mu \mathrm{g} / \mathrm{mL}$ (Table 1) [11]. Many compounds such as polysin, greenwayodendrin3-one, 3-O-acetyl greenwayodendrin, $\mathrm{N}$-acetylpolyveoline, polyveoline [18], and several alkaloids including indolosesquiterpenes and aporphines have been isolated from the plant [17].

2.2.25. Phyllanthus amarus Schumach. \& Thonn. Phyllanthus amarus is a small herb well known for its medicinal properties and widely used worldwide [44]. It is useful in gastropathy, diarrhoea, dysentery, intermittent fevers, ophthalmopathy, scabies, ulcers, and wounds [44]. The aqueous extract of $P$. amarus, used in traditional medicine in Ivory Coast to treat incurable wounds, has demonstrated in vitro activity against M. ulcerans strain 02003 with $\mathrm{IC}_{50}$ and $\mathrm{IC}_{90}$ values, respectively, of $3.5 \mathrm{mg} / \mathrm{mL}$ and $19.8 \mathrm{mg} / \mathrm{mL}$ and was bactericidal at concentrations of $64 \mathrm{mg} / \mathrm{mL}$ [103]. Coulibaly et al. [43] have demonstrated the growth inhibition activity of aqueous and ethanolic extracts of $P$. amarus on $7 \mathrm{M}$. ulcerans isolates in vitro with similar MIC of $32 \mathrm{mg} / \mathrm{mL}$ (Table 1). P. amarus have numerous active phytocompounds such as alkaloids, flavonoids, tannins, lignans, polyphenolic compounds, and tetracyclic triterpenoids [44]. Though the main use of $P$. amarus traditionally is to treat tuberculosis [104] rather than Buruli ulcer, its in vitro effect on M. ulcerans supports its traditional use against Buruli ulcer [43].

2.2.26. Sacoglottis gabonensis (Baill.) Urb. Sacoglottis gabonensis is a large, evergreen tree up to $40 \mathrm{~m}$ tall and it is used to cure many ailment, namely, difficult cases of dermatitis [34] and Buruli ulcer. A decoction of the stem bark of the plant is administered orally or used topically to disinfect the ulcer or the ulcer is covered with fine powder of the stem bark and bandaged [33]. The aqueous extract of S. gabonensis showed promising activity against $M$. ulcerans in vitro (MIC = $780 \mu \mathrm{g} / \mathrm{mL}$ ) [33] (Table 1). Bergenin, an isocoumarin, was identified as the main active compound of the stem bark extract of S. gabonensis [34]. Further analyses of stem bark extract have shown tannins, sterols, polyterpenes, polyphenols, flavonoids, and alkaloids in appreciable amounts with a trace of saponins. The stem bark also contains 2 cis/trans isomers of lignans (calopiptin and galgravin) [34]. Sofowora [35] has also reported that these compounds are responsible for the biological activities of the plant. Kamanzi [105] also argued that plants show antibacterial activity when they contain flavonoids, tannins, saponins, and alkaloids.

2.2.27. Tonic 1: Mixture of Zea mays L. and Spigelia anthelmia L. Mixture of S. anthelmia leaves and Z. mays (tonic 1) used in traditional BU treatment [5] showed growth inhibition of 7
M. ulcerans with MIC values of 6.25-25 $\mu \mathrm{g} / \mathrm{mL}$ (cited as 3.13$12.5 \%(\mathrm{~V} / \mathrm{V}))$ (Table 1) [5].

(i) Spigelia anthelmia L. Spigelia anthelmia is a common annual weed that grows in open regrowths, on unused land in towns and on road sides [106]. The plant is reputed to be useful in wound healing. A decoction of leaves and twigs is used to wash the wound, which is then dressed with a powder of the bark of the plant [107]. Phytochemical investigation has described the isolation of the alkaloid spiganthine, volatile alkaloids, isoquinoline and actinide isomer, three quaternary alkaloids, choline, benzoylcholine and 2,3-dimethylacrolyl choline, phenylcarboxylic acids, and flavonoids [54, 55] from the plant.

(ii) Zea mays L. Zea mays is a robust annual grass up to 4(6) $m$ tall [108] that possesses wound healing activity [109]. $Z$. mays corn silk is rich in phenolic compounds, particularly flavonoids. It also consists of proteins, vitamins, carbohydrates, calcium, potassium, magnesium and sodium salts, volatiles oils, and steroids such as sitosterol and stigmasterol, alkaloids, and saponins [56] that might promote the wound healing and antibacterial activities of the mixture.

2.2.28. Tonic 2: Mixture of Citrus aurantifolia (Christm.) Swingle and Gossypium barbadense L. It consists of C. aurantifolia mixed with $G$. barbadense and inhibits the growth of 7 M. ulcerans isolates with MIC values of $12.5-25 \mu \mathrm{g} / \mathrm{mL}$ (cited as $6.25-12.5 \%(\mathrm{~V} / \mathrm{V}))$ (Table 1) [5].

(i) Citrus aurantifolia (Christm.) Swingle. Citrus aurantifolia is widespread in tropical and subtropical regions around the world and it is known for its nutritional values and flavour [110]. The plant and fruit of C. aurantifolia have been commonly used in traditional medicine to treat various diseases [110] including Buruli ulcer. It is used either alone as decoction or mixed with $G$. barbadense leaves or S. campanulata as a bandage for ulcer $[4,5,20,68,88]$. The essential oil of C. aurantifolia fruits contain mainly limonene, betapinene, gamma-terpinene, and citral [111]. The methanolic extract of C. aurantifolia contains alkaloids, flavonoids, tannins, saponins, steroids, cardiac glycosides, and reducing sugar [57]. The hexane extract of the fruit peels fractionated by column chromatography yielded the following major compounds: 5-geranyloxypsoralen, 5-geranyloxy-7-methoxycoumarin, 5,7-dimethoxycoumarin, 5-methoxypsoralen, and 5,8-dimethoxypsoralen. In addition, GC-MS analysis of the hexane extract allowed for the identification of 44 volatile compounds, where 5,7-dimethoxycoumarin, 3-methyl-1,2cyclopentanedione, 1-methoxy-ciclohexene, corylone, palmitic acid, 5,8-dimethoxypsoralen, $\alpha$-terpineol, and umbelliferone are the major constituents. Some constituents that have shown activity against Mycobacterium tuberculosis strains were 5,8-dimethoxypsoralen (MICs $=25-50 \mu \mathrm{g} / \mathrm{mL}$ ), 5 -geranyloxypsoralen $(\mathrm{MICs}=50-100 \mu \mathrm{g} / \mathrm{mL})$, palmitic acid $(\mathrm{MICs}=25-50 \mu \mathrm{g} / \mathrm{mL})$, linoleic acid (MICs $=50-$ $100 \mu \mathrm{g} / \mathrm{mL})$, oleic acid (MICs $=100 \mu / \mathrm{mL}), 4$-hexen-3-one $(\mathrm{MICs}=50-100 \mu \mathrm{g} / \mathrm{mL})$, and citral $(\mathrm{MICs}=50-100 \mu \mathrm{g} / \mathrm{mL})$ [110]. The antimycobacterial activity of C. aurantifolia against 
<smiles>CNC1CCC2(C)C(=CCC3C2CCC2(C)C(C(C)O)=CCC32)C1</smiles>

Holadysamine

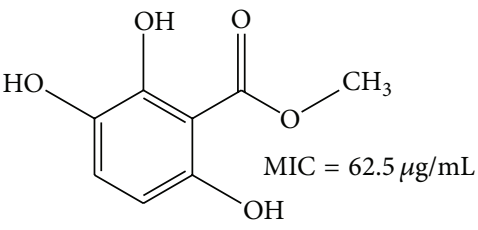

2,3,6-Trihydroxymethyl benzoate<smiles>CC(C)C1=CCC2C3CC=C4CC(N(C)C)CCC4(C)C3CCC12C</smiles>

Proposed chemical structure for compound C<smiles>C[C@@H](O)C1CCC2C3CC=C4CC(N(C)C)CCC4(C)C3CCC21C</smiles>

Holaphyllinol<smiles>CC(=O)C1CCC2C3CC=C4C[C@@H](N)CCC4(C)C3CCC12C</smiles>

Compound B: $\mathrm{H}, \underset{\text { or }}{\text { a }}$ holaphyllamine

$\mathrm{H}$, ....num! holamine

Figure 1: Potent anti-Mycobacterium ulcerans compounds isolated from plants.

M. ulcerans could be attributed to these compounds and might have significantly contributed to the observed potency of the mixture.

(ii) Gossypium barbadense L. G. barbadense is an annual herb that has been reported to have many therapeutic effects including treatment of cutaneous and subcutaneous parasitic infections are mostly attributed to its active constituent gossypol [58].

\subsubsection{Tonic 3: Mixture of Jatropha curcas, Gossypium hirsu-} tum, Physalis angulate, and Delonix regia. Tonic 3 consisting of J. curcas mixed with G. hirsutum, P. angulata, and D. regia inhibits the growth of $7 \mathrm{M}$. ulcerans isolates with MIC value of 6.25-25 $\mu \mathrm{g} / \mathrm{mL}$ (reported as 3.13-12.5\% (V/V)) (Table 1) [5].

(i) Jatropha curcas L. See the above.

(ii) Physalis angulata L. Physalis angulata is a much branched annual shrub, perennial in subtropical zones, and can grow until it reaches $1.0 \mathrm{~m}$. It is used in several countries of tropical and subtropical regions of the world as medicinal and fruit tree. Recent ethnopharmacological studies show that $P$. angulata leaf paste is used as an external application for wounds [59]. The major identifiable phytochemical constituents of medicinal importance are physalins and withanolides [59, 60]. The anti-inflammatory, antimycobacterial, antinociceptive, and antitumor activities together with the inhibitory effect on M. Ulcerans support its traditional uses for Buruli ulcer treatment.

(iii) Gossypium hirsutum L. Gossypium hirsutum is a perennial shrubs also known as upland cotton or Mexican cotton. It is native to Mexico. Extract from cotton plant, which would be primarily gossypol, has been used as traditional medicine. Cotton leaves have been used as a treatment for nausea during pregnancy, for "proud flesh" (swollen tissue around a wound) or for fungal infections. Cotton tissue, particularly the seeds, can be toxic if ingested in excessive quantities because of the presence of antinutritional and toxic factors including gossypol and cyclopropenoid fatty acids (including dihydrosterculic, sterculic, and malvalic acids) [61, 62].

(iv) Delonix regia (Hook.) Raf. Delonix regia is broad, spreading, flat crowned deciduous tree found in tropical areas. Phytochemical studies of D. Regia have shown the presence of sterols, triterpenoids, phenolic compounds, flavonoids, sugars, tannins, steroids, $\beta$-sitosterol, lupeol, hydrocarbons phytotoxins, saponins $[63,64]$, and an aromatic compound, p-methoxybenzaldehyde. Adje et al. [65] characterized three major anthocyanins: cyanidin 3-O-glucoside, cyanidin 3-Orutinoside, and pelargonidin 3-O-rutinoside; three sterols (stigmasterol, $\beta$-sitosterol, and its 3-O-gucoside); a triterpene (ursolic acid) and four flavonoids (quercetin, quercitrin, isoquercitrin, and rutin) [112]. Ethanolic and aqueous extracts of $D$. regia flowers containing $\beta$-sitosterol and stigmasterol 
significantly promoted the healing process in rat [113] supporting its usage in the treatment of Buruli ulcer.

2.3. Anti-Mycobacterium ulcerans Compounds Isolated from Plants. Five active compounds with MICs ranging from 50 to $125 \mu \mathrm{g} / \mathrm{mL}$ have been isolated from two plants: one from Sorindeia juglandifolia (2,3,6-trihydroxymethyl benzoate) [11] and four from Holarrhena floribunda (holadysamine, holaphyllinol, holamine/holaphyllamine, compound C required further analysis to confirm the structure) [21] (see Figure 1).

\section{Conclusion and Future Perspectives}

In this review, we have discussed medicinally significant plant species from Sub-Saharan Africa and showed that many have activity against M. ulcerans. Currently, there are only two studies that have reported the purification of active compounds against M. ulcerans. This highlights the poor emphasis given to research into new chemotherapeutic agents against one of the world most neglected diseases: Mycobacterium ulcerans disease. The present review can be used to validate ethnomedicinal knowledge and bioactivities. Unfortunately, most of the species that are claimed to contain antimycobacterial activities have not been studied in vivo. Screening with in vitro assays has little meaning if there is no clear evidence of effectiveness of the extracts in vivo. Therefore, further in vivo studies of preparations from the identified plant species are required. This should be followed by systematic phytochemical studies of plants that contain bioactive antimycobacterial activities, isolation, and characterization of the anti-M. ulcerans chemical entities. These can provide the needed validation before such chemical entities can be used as sustainable cheaper/alternative medicines for management of Buruli ulcer disease.

\section{Conflict of Interests}

The authors declare that they have no conflict of interests regarding the publication of this paper.

\section{Acknowledgment}

The authors are grateful to Noguchi Memorial Institute for Medical Research, University of Ghana, for hosting Patrick Valere Tsouh Fokou under a Postdoctoral Research Fellowship financially supported by the Bill and Melinda Gates Foundation.

\section{References}

[1] R. C. Johnson, M. Makoutode, R. Hougnihin et al., "Traditional treatment for Buruli ulcer in Benin," Medécine Tropicale, vol. 64, no. 2, pp. 145-150, 2004.

[2] Y. Stienstra, W. T. A. van der Graaf, K. Asamoa, and T. S. van der Werf, "Beliefs and attitudes toward Buruli ulcer in Ghana," The American Journal of Tropical Medicine and Hygiene, vol. 67, no. 2, pp. 207-213, 2002.
[3] E. N. Adjanohoun, K. Aboubakar, M. E. Dramane et al., Traditional Medicine and Pharmacopoiea. Contribution to Ethnobotanical and Floristic Studies in Cameroon, Scientific, Technical and Research Commission of the OAU (STRC/OAU), 1996.

[4] A. L. Yemoa, J. D. Gbenou, R. C. Johnson et al., "Identification et étude phytochimique de plantes utilisées dans le traitement traditionnel de l'ulcère de Buruli au Bénin," Ethnopharmacologia, vol. 42, pp. 50-57, 2008.

[5] P. Addo, M. Quartey, M. Abbas et al., "In-vitro susceptibility of Mycobacterium ulcerans to herbal preparations," The Internet Journal of Tropical Medicine, vol. 4, no. 2, 2007.

[6] S. O. Udegbunam, R. I. Udegbunam, C. C. Muogbo, M. U. Anyanwu, and C. O. Nwaehujor, "Wound healing and antibacterial properties of methanolic extract of Pupalia lappacea Juss in rats," BMC Complementary and Alternative Medicine, vol. 14, article 157, 2014.

[7] R. Pandiyan, L. Subbiah, S. Palaniswamy, S. Ariyamuthu, T. Muthuswamy, and R. K. Velu, "A wide array on anti-inflammatory study in an ethanolic extracts of Pupalialappaceae juss. (Amaranthaceae) by using wistar rats, Scholars Research Library," Archives of Applied Science Research, vol. 1, no. 2, pp. 150-158, 2009.

[8] P. P. Naidu, M. Madakka, and B. Rajesh, "Pupalia lappacea Juss [L]: a review of phytochemistry and therapeutic application," Asian Journal of Pharmaceutical and Clinical Research, vol. 7, no. 1, pp. 15-18, 2014.

[9] N. N. Zhao, H. Zhang, X. C. Zhang et al., "Evaluation of acute toxicity of essential oil of garlic (Allium sativum) and its selected major constituent compounds against overwintering Cacopsylla chinensis (Hemiptera: Psyllidae)," Journal of Economic Entomology, vol. 106, no. 3, pp. 1349-1354, 2013.

[10] WHO, WHO Monographs on Selected Medicinal Plants, vol. 1, World Health Organization, Geneva, Switzerland, 1999.

[11] V. F. D. Donfack, S. Roque, G. Trigo et al., "Antimycobacterial activity of selected medicinal plants extracts from Cameroon," International Journal of Biological and Chemical Sciences, vol. 8, no. 1, pp. 273-288, 2014.

[12] R. G. Kamkumo, A. M. Ngoutane, L. R. Y. Tchokouaha et al., "Compounds from Sorindeia juglandifolia (Anacardiaceae) exhibit potent anti-plasmodial activities in vitro and in vivo," Malaria Journal, vol. 11, article 382, 2012.

[13] J. T. Ndongo, J. N. Mbing, D. N. Bikobo et al., "A new C-Glucosylflavone from Sorindeia juglandifolia," Zeitschrift für Naturforschung C, vol. 68, no. 5-6, pp. 169-174, 2013.

[14] G. D. W. F. Kapche, H. Laatsch, S. Fotso et al., "Lanneanol: a new cytotoxic dihydroalkylcyclohexenol and phenolic compounds from Lannea nigritana (Sc. Ell.) Keay," Biochemical Systematics and Ecology, vol. 35, no. 8, pp. 539-543, 2007.

[15] H. K. Kimbi and A. F. Fagbenro-Beyioku, "Efficacy of Cymbopogon giganteus and Enantia chrantha against chloroquine resistant Plasmodium yoelii nigeriensis," East African Medical Journal, vol. 73, no. 10, pp. 636-637, 1996.

[16] H. M. Malebo, T. Wenzler, M. Cal et al., "Anti-protozoal activity of aporphine and protoberberine alkaloids from Annickia kummeriae (Engl. \& Diels) Setten \& Maas (Annonaceae)," BMC Complementary and Alternative Medicine, vol. 13, article 48, 2013.

[17] T. R. B. Jiofack, "Greenwayodendron suaveolens (Engl. \& Diels) Verdc," in Prota 7(2): Timbers/Bois d'Euvre 2, R. H. M. J. Lemmens, D. Louppe, and A. A. Oteng-Amoako, Eds., [CD-Rom], PROTA, Wageningen, The Netherlands, 2011. 
[18] I. Ngantchou, B. Nyasse, C. Denier, C. Blonski, V. Hannaert, and B. Schneider, "Antitrypanosomal alkaloids from Polyalthia suaveolens (Annonaceae): their effects on three selected glycolytic enzymes of Trypanosoma brucei," Bioorganic and Medicinal Chemistry Letters, vol. 20, no. 12, pp. 3495-3498, 2010.

[19] J. P. K. Adotey, G. E. Adukpo, Y. O. Boahen, and F. A. Armah, “A review of the ethnobotany and pharmacological importance of Alstonia boonei De Wild (Apocynaceae)," ISRN Pharmacology, vol. 2012, Article ID 587160, 9 pages, 2012.

[20] A. Yemoa, J. Gbenou, D. Affolabi et al., "Beninese medicinal plants as a source of antimycobacterial agents: bioguided fractionation and in vitro activity of alkaloids isolated from Holarrhena floribunda used in traditional treatment of buruli ulcer," BioMed Research International, vol. 2015, Article ID 835767, 5 pages, 2015.

[21] A. Yemoa, J. Gbenou, D. Affolabi et al., "Buruli ulcer: a review of in vitro tests to screen natural products for activity against Mycobacterium ulcerans," Planta Medica, vol. 77, no. 6, pp. 641646, 2011.

[22] G. H. Schmelzer, "Holarrhena floribunda (G.Don) T.Durand \& Schinz. [Internet] record from PROTA4U," in Plant Resources of Tropical Africa, G. H. Schmelzer and A. Gurib-Fakim, Eds., PROTA, Wageningen, The Netherlands, 2006, http://www.prota4u.org/search.asp.

[23] T. C. Fuller and E. M. McClintock, Poisoneous Plant of California, University of California Press, Los Angeles, Calif, USA, 1986.

[24] Z. Zaheer, A. P. Paithankar, S. D. Deshpande, S. Khan, and R. Z. Ahmed, "Comparative phytochemical screening of flowers and bark of Spathodea campanulata," Journal of Applied Biology and Pharmaceutical Technology, vol. 2, no. 1, pp. 233-235, 2011.

[25] E. E. Ilodigwe, P. A. Akah, and C. S. Nworu, "Anticonvulsant activity of ethanol leaf extract of Spathodea campanulata P. Beauv (Bignoniaceae)," Journal of Medicinal Food, vol. 13, no. 4, pp. 827-833, 2010.

[26] E. E. Ilodigwe, P. A. Akah, and C. S. Nworu, "Evaluation of the acute and subchronic toxicities of ethanol leaf extract of Spathodea campanulata P. Beauv," International Journal of Applied Research in Natural Products, vol. 3, no. 2, pp. 17-21, 2010.

[27] T. Panduraju, B. Parvathi, M. Rammohan, and C. S. Reddy, "Wound healing properties of Cleome viscosa linn," Hygeia: Journal for Drugs and Medicines, vol. 3, no. 1, pp. 41-45, 2011.

[28] A. Upadhyay, P. Chattopadhyay, D. Goyary, P. M. Mazumder, and V. Veer, "Topical application of Cleome viscosa increases the expression of basic fibroblast growth factor and type III collagen in rat cutaneous wound," BioMed Research International, vol. 2014, Article ID 680879, 7 pages, 2014.

[29] C. F. Bosi, D. W. Rosa, R. Grougnet et al., "Pyrrolizidine alkaloids in medicinal tea of Ageratum conyzoides," Brazilian Journal of Pharmacognosy, vol. 23, no. 3, pp. 425-432, 2013.

[30] O. Kolawole, S. O. Oguntoye, O. Agbede, and A. B. Olayemi, "Studies on the efficacy of Bridelia ferruginea Benth. bark extract in reducing coliform load and BOD of domestic wastewater," Ethnobotanical Leaflets, vol. 10, pp. 228-238, 2006.

[31] T. De Bruyne, K. Cimanga, L. Pieters, M. Claeys, R. Dommisse, and A. Vlietinck, "Gallocatechin - $\left(4^{\prime} \quad \rightarrow 0 \rightarrow 7\right)$ - epigallocatechin, a new biflavonoid isolated from Bridelia ferruginea," Natural Product Letters, vol. 11, no. 1, pp. 47-52, 1997.

[32] D. M. R. Prasad, A. Izam, and M. M. R. Khan, "Jatropha curcas: plant of medical benefits," Journal of Medicinal Plants Research, vol. 6, pp. 2691-2699, 2012.
[33] M. Kone, O. M. Vangah-Manda, H. Kouakou, A. P. Yapo, N. M. Bléyéré, and Y. J. Datté, "Influence de Sacoglottis gabonensis (Baille) Urban et de Okoubaka aubrevillei Normand et Pellegrin sur la croissance in vitro de Mycobacterium ulcerans," Médecine d'Afrique Noire, vol. 54, pp. 549-554, 2007.

[34] E. Dounias, "Sacoglottis Gabonensis (Baill.) Urb," in Prota 11(1): Medicinal Plants/Plantes Médicinales 1., G. H. Schmelzer and A. Gurib-Fakim, Eds., PROTA, Wageningen, The Netherlands, 2008.

[35] A. Sofowora, Plantes Médicinales et Médecine Traditionnelle d'Afrique, Karthala, Paris, France, 1996.

[36] M. Kone, N. M. Bleyere, A. P. Yapo, M. O. Vangah, and E. E. Ehile, "Evaluation de la toxicité d'un extrait aqueux de Sacoglottis gabonensis (Baille) Urban (Humiriaceae) chez les rongeurs, une plante utilisée dans le traitement de l'ulcère de Buruli en Côte d'Ivoire," International Journal of Biological and Chemical Sciences, vol. 3, no. 6, pp. 1286-1296, 2009.

[37] A. U. Ogan, "An isocoumarin from the bark of Sacoglottis gabonensis," Phytochemistry, vol. 10, no. 11, pp. 2832-2833, 1971.

[38] A. Bouquet and M. Debray, Plantes Médicinales de la Côte d'Ivoire, ORSTOM, Paris, France, 1974.

[39] J. P. Yadav, V. Arya, S. Yadav, M. Panghal, S. Kumar, and S. Dhankhar, "Cassia occidentalis L.: a review on its ethnobotany, phytochemical and pharmacological profile," Fitoterapia, vol. 81, no. 4, pp. 223-230, 2010.

[40] A. M. Metwally, A. A. Omar, N. M. Ghazy, F. M. Harraz, and S. M. El Sohafy, "Monograph of Psidium guajava L. leaves," Pharmacognosy Journal, vol. 3, pp. 89-104, 2011.

[41] M. Mittal, N. Gupta, P. Parashar, V. Mehra, and M. Khatri, "Phytochemical evaluation and pharmacological activity of Syzygium aromaticum: a comprehensive review," International Journal of Pharmacy and Pharmaceutical Sciences, vol. 6, no. 8, pp. 67-72, 2014.

[42] M. Zia-Ul-Haq, A. Kausar, S. A. Shahid, M. Qayum, S. Ahmad, and I. Khan, "Phytopharmacological profile of Gratiola officinalis Linn.: a review," Journal of Medicinal Plants Research, vol. 6, no. 16, pp. 3087-3092, 2012.

[43] B. Coulibaly, K. R. N'guessan, N. Aka et al., "Activité anti-mycobactérienne in vitro des extraits de Phyllanthus amarus (Schum et Thonn) sur les souches de Mycobacterium ulcerans en Côte d'Ivoire," Bulletin de la Société Royale des Sciences de Liège, vol. 80, pp. 759-771, 2011.

[44] J. R. Patel, P. Tripathi, V. Sharma, N. S. Chauhan, and V. K. Dixit, "Phyllanthus amarus: ethnomedicinal uses, phytochemistry and pharmacology: a review," Journal of Ethnopharmacology, vol. 138, no. 2, pp. 286-313, 2011.

[45] M. Christian, "Steroids-chemical constituents of Phyllanthus fraternus Webster through TLC and HPTLC," International Research Journal of Chemistry, pp. 29-48, 2013.

[46] A. Pengelly, K. Bennett, K. Spelman, and M. Tims, Appalachian Plant Monographs: Hydrastis canadensis L., Goldenseal, Appalachian Center for Ethnobotanical Studies, 2012.

[47] E. N. Matu, "Zanthoxylum zanthoxyloides (Lam.) Zepern. \& Timler," in Record from PROTA4U, G. H. Schmelzer and A. Gurib-Fakim, Eds., PROTA (Plant Resources of Tropical Africa/Ressources Végétales de l'Afrique Tropicale), Wageningen, The Netherlands, 2011, http://www.prota4u.org/search.asp.

[48] C. Lagu and F. B. I. Kayanja, "Acute toxicity profiles of aqueous and ethanolic extracts of Capsicum annum seeds from South Western Uganda," in Insights from Veterinary Medicine, R. Payan-Carreira, Ed., InTech, 2013. 
[49] A. WesoŁowska, D. Jadczak, and M. Grzeszczuk, "Chemical composition of the pepper fruit extracts of hot cultivars Capsicum annuum L," Acta Scientiarum Polonorum, Hortorum Cultus, vol. 10, no. 1, pp. 171-184, 2011.

[50] M. Mohan and S. Bhandare, "Protective effect of Solanum torvum against testicular toxicity in male wistar rats," International Journal of Pharmacy and Pharmaceutical Sciences, vol. 4, no. 3, pp. 188-192, 2012.

[51] A. Surjushe, R. Vasani, and D. G. Saple, "Aloe vera: a short review," Indian Journal of Dermatology, vol. 53, no. 4, pp. 163166, 2008.

[52] P. K. Mukherjee, N. K. Nema, N. Maity, K. Mukherjee, and R. K. Harwansh, "Phytochemical and therapeutic profile of Aloe vera," Journal of Natural Remedies, vol. 14, no. 1, pp. 1-26, 2014.

[53] J. van Ingen, M. J. Boeree, D. van Soolingen, and J. W. Mouton, "Resistance mechanisms and drug susceptibility testing of nontuberculous mycobacteria," Drug Resistance Updates, vol. 15, no. 3, pp. 149-161, 2012.

[54] S. M. de Morais, C. M. Beviláqua, J. A. Souza, and L. M. Assis, "Chemical investigation of Spigelia anthelmia Linn. used in Brazilian folk medicine as anthelmintic," Revista Brasileira de Farmacognosia, vol. 12, pp. 81-82, 2002.

[55] L. J. G. van der Maesen, “Spigelia anthelmia L," in Prota 11(1): Medicinal Plants/Plantes Médicinales 1, G. H. Schmelzer and A. Gurib-Fakim, Eds., PROTA, Wageningen, The Netherlands, 2007.

[56] K. Hasanudin, P. Hashim, and S. Mustafa, "Corn silk (Stigma Maydis) in healthcare: a phytochemical and pharmacological review," Molecules, vol. 17, no. 8, pp. 9697-9715, 2012.

[57] S. S. Akhtar, "Evaluation of cardiovascular effects of Citrus aurantifolia (Linn.) fruit," Social Science Research Network, 2013, http://ssrn.com/abstract=2279447.

[58] Z. Muhammad, S. Atabo, and A. Zakari, "Characterization of bioactive components of Gossypium barbadense L. with hematinic potential in Wister albino rats," British Journal of Pharmaceutical Research, vol. 4, no. 21, pp. 2563-2574, 2014.

[59] E. Rengifo-Salgado and G. Vargas-Arana, "Physalis angulata L. (Bolsa Mullaca): a review of its traditional uses, chemistry and pharmacology," Boletín Latinoamericano y del Caribe de Plantas Medicinales y Aromáticas, vol. 12, no. 5, pp. 431-445, 2013.

[60] C. Rathore, K. R. Dutt, S. Sahu, and L. Deb, "Antiasthmatic activity of the methanolic extract of Physalis angulata Linn," Journal of Medicinal Plant Research, vol. 5, no. 22, pp. 5351-5355, 2011.

[61] A. W. Franck, "Food uses of cottonseed protein," in Development in Food Proteins, pp. 31-80, Elsevier Applied Science, New York, NY, USA, 1989.

[62] M. E. Ensminger, J. E. Oldfield, and W. W. Heinemann, "Excerpts with reference to cottonseed and cottonseed components," in Feeds and Nutrition, M. E. Ensminger, Ed., pp. 252474, Ensminger Publishing Company, Clovis, Calif, USA, 1990.

[63] S. S. Azab, M. Abdel-Daim, and O. A. Eldahshan, "Phytochemical, cytotoxic, hepatoprotective and antioxidant properties of Delonix regia leaves extract," Medicinal Chemistry Research, vol. 22, no. 9, pp. 4269-4277, 2013.

[64] S. P. S. Shabudeen, S. Daniel, and P. Indhumathi, "Utilising the pods of Delonix regia activated carbon for the removal of mercury (II) by adsorption technique," International Journal of Research in Chemistry and Environment, vol. 3, pp. 60-65, 2013.

[65] F. Adje, Y. F. Lozano, E. Meudec et al., "Anthocyanin characterization of pilot plant water extracts of Delonix regia flowers," Molecules, vol. 13, no. 6, pp. 1238-1245, 2008.
[66] N. Scherr, K. Röltgen, M. Witschel, and G. Pluschke, "Screening of antifungal azole drugs and agrochemicals with an adapted alamarblue-based assay demonstrates antibacterial activity of croconazole against Mycobacterium ulcerans," Antimicrobial Agents and Chemotherapy, vol. 56, no. 12, pp. 6410-6413, 2012.

[67] A. Martin, M. Camacho, F. Portaels, and J. C. Palomino, "Resazurin microtiter assay plate testing of Mycobacterium tuberculosis susceptibilities to second-line drugs: rapid, simple, and inexpensive method," Antimicrobial Agents and Chemotherapy, vol. 47, no. 11, pp. 3616-3619, 2003.

[68] L. Seefeld, E. O. Lartey, M. Schindler-Piontek, A. Gerhardus, and O. Razum, Herbal Remedies used by BU Patients in the Eastern Region of Ghana, BU-WHO Meeting, Geneva, Switzerland, 2013.

[69] J. Bruneton, Pharmacognosy, Phytochemistry, Medicinal Plants, Technique \& Documentation-Lavoisier, Paris, France, 1995.

[70] R. H. Davis, J. J. Donato, G. M. Hartman, and R. C. Haas, "Anti-inflammatory and wound healing activity of a growth substance in Aloe vera," Journal of the American Podiatric Medical Association, vol. 84, no. 2, pp. 77-81, 1994.

[71] U. M.-E. Dibua, C. C. Okeke, C. Ugwu, F. C. Kenechukwu, and A. Okorie, "In vivo antimalarial and cytotoxicity activity of ethanolic stem bark of Petersianthus macrocarpus and leaf of Astonia boonei in experimental mice model," International Journal of Current Microbiololgy and Applied Science, vol. 2, no. 12, pp. 354-368, 2013.

[72] P. O. Igbinaduwa and O. Obasuyi, "Phytochemical screening and antibacterial activity of stem bark extract of Alstonia Boonei Dewild (Apocynaceae)," Journal of Pharmaceutical and Allied Sciences, vol. 9, no. 3, pp. 1574-1579, 2012.

[73] S. A. Chime, E. C. Ugwuoke, I. V. Onyishi, S. A. Brown, and G. C. Onunkwo, "Formulation and evaluation of Alstonia boonei stem bark powder tablets," Indian Journal of Pharmaceutical Sciences, vol. 75, no. 2, pp. 226-230, 2013.

[74] A. J. Akindele, O. A. Salako, and U. V. Ohonbamu, "Evaluation of the antidiarrhoeal activity of the hydroethanolic leaf extract of Pupalia lappacea Linn. Juss. (Amaranthaceae)," Journal of Ethnopharmacology, vol. 151, no. 2, pp. 984-989, 2014.

[75] F. H. Kamel, H. M. Ismael, and A. A. Ahmed, "Effect of natural surface secretes of some common ornamental plants leaves on pathogenic micro-organisms," Journal of Life Sciences, vol. 6, pp. 1387-1390, 2012.

[76] A. S. Diallo, K. Eklu-Gadegkeku, A. Agbonon, K. Aklikokou, E. E. Creppy, and M. Gbeassor, "Acute and sub-chronic (28-day) oral toxicity studies of hydroalcohol leaf extract of Ageratum conyzoides L (Asteraceae)," Tropical Journal of Pharmaceutical Research, vol. 9, no. 1, pp. 463-467, 2010.

[77] F. Mohammad and M. Avijit, "Wound healing potentiality of methanolic extract of Aerial Parts of Cleome viscose," International Journal of PharmTech Research, vol. 5, no. 3, pp. 978-982, 2013.

[78] R. P. Wunderlin and B. F. Hansen, Guide to the Vascular Plants of Florida, University Press of Florida, Gainsville, Fla, USA, 2nd edition, 2003.

[79] B. M. Matur, T. Matthew, and C. I. C. Ifeanyi, "Analysis of the phytochemical and in vivo antimalaria properties of Phyllanthus fraternus Webster extract," New York Science Journal, vol. 2, no. 5, pp. 12-19, 2009.

[80] T. Leslie, Herbal Secrets of the Rainforest, Traditional Medicine, Sage Press Incorporated, WHO, Geneva, Switzerland, 2nd edition, 2003, edited by: WHO. 
[81] O. A. Fabiyi, A. Olubunmi, O. S. Adeyemi, and G. A. Olatunji, "Antioxidant and Cytotoxicity of $\beta$-Amyrin acetate fraction from Bridelia ferruginea leaves," Asian Pacific Journal of Tropical Biomedicine, vol. 2, no. 2, pp. S981-S984, 2012.

[82] M. G. B. Silva, T. P. Aragão, C. F. B. Vasconcelos et al., "Acute and subacute toxicity of Cassia occidentalis L. stem and leaf in Wistar rats," Journal of Ethnopharmacology, vol. 136, no. 2, pp. 341-346, 2011.

[83] M. Kaneria and S. Chanda, "Phytochemical and pharmacognostic evaluation of leaves of Psidium guajava L. (Myrtaceae)," Pharmacognosy Journal, vol. 3, no. 23, pp. 41-45, 2011.

[84] K. Mejia and E. Rengifo, Plantas Medicinales de Uso Popular en la Amazonía Peruana, Tarea Asociación Gráfica Educativa, Lima, Peru, 2nd edition, 2000.

[85] M. Ayyanar and S. Ignacimuthu, "Herbal medicines for wound healing among tribal people in Southern India: ethnobotanical and scientific evidences," International Journal of Applied Research in Natural Products, vol. 2, no. 3, pp. 29-42, 2009.

[86] A. D. Agrawal, P. S. Bajpei, A. A. Patil, and S. R. Bavaskar, "Solanum torvum Sw.- a phytopharmacological review," Der Pharmacia Lettre, vol. 2, no. 4, pp. 403-407, 2010.

[87] R. R. Schippers, "Solanum torvum Sw," in PROTA 2: Vegetables/Légumes, G. J. H. Grubben and O. A. Denton, Eds., [CDRom], PROTA, Wageningen, The Netherlands, 2004.

[88] A. Adjet, G. Fokou, D. Kouame, and L. Mosi, "Soins de l'ulcere de buruli dans le district sanitaire de Yamoussoukro," in Conférence Internationale Africa 2013 sur l'Ecosanté, 2013.

[89] G. H. Sam, F. Adu, and K. Annan, "Ethnobotanical survey of medicinal plants used for the treatment of diarrhoea and skin ulcer in the Brong Ahafo region of Ghana," Journal of Medicinal Plants Research, vol. 7, pp. 3280-3285, 2013.

[90] V. P. Londhe, A. T. Gavasane, S. S. Nipate, D. D. Bandawane, and P. D. Chaudhari, "Role of garlic (Allium sativum) in various diseases: an overview," Journal of Pharmaceutical Research and Opinion, vol. 1, no. 4, pp. 129-134, 2011.

[91] I. C. D. Timotius, S. Puradisastra, and H. Tiono, "Effect of garlic tuber juice (Allium sativum L.) in wound healing shorten the duration of swiss webster mice," Journal of Pharmaceutical Research and Opinion, vol. 1, no. 4, pp. 129-134, 2011.

[92] K. Sidik, A. A. Mahmood, and I. Salmah, "Acceleration of wound healing by aqueous extract of Allium sativum in combination with honey on cutaneous wound healing in rats," International Journal of Molecular Medicine and Advance Sciences, vol. 2, no. 2, pp. 231-235, 2006.

[93] W. Paul and C. P. Sharma, "Chitosan and alginate wound dressings: a short review," Trends in Biomaterials and Artificial Organs, vol. 18, pp. 18-23, 2004.

[94] H. Tobe and R. C. Keating, "The morphology and anatomy of Hydrastis (Ranunculales): systematic reevaluation of the genus," The Botanical Magazine Tokyo, vol. 98, no. 3, pp. 291-316, 1985.

[95] E. J. Gentry, H. B. Jampani, A. Keshavarz-Shokri et al., "Antitubercular natural products: berberine from the roots of commercial Hydrastis canadensis powder. Isolation of inactive 8oxotetrahydrothalifendine, canadine, $\beta$-hydrastine, and two new quinic acid esters, hycandinic acid esters-1 and -2," Journal of Natural Products, vol. 61, no. 10, pp. 1187-1193, 1998.

[96] J. W. Ogwal-Okeng, C. Obua, and W. W. W. Anokbonggo, "Acute toxicity effects of the methanolic extract of Fagara zanthoxyloides (Lam.) root-bark," African Health Sciences, vol. 3, no. 3, pp. 124-126, 2003.

[97] X.-Q. Zhang, F. Li, Z.-G. Zhao, X.-L. Liu, Y.-X. Tang, and M.-K. Wang, "Diterpenoids from the root bark of Jatropha curcas and their cytotoxic activities," Phytochemistry Letters, vol. 5, no. 4, pp. 721-724, 2012.

[98] S. Shetty, S. L. Udupa, A. L. Udupa, and V. R. Vollala, "Wound healing activities of bark extract of Jatropha curcas Linn in albino rats," Saudi Medical Journal, vol. 27, no. 10, pp. 1473-1476, 2006.

[99] J. M. Dalziel, The Useful Plants of West Tropical Africa, The Crown Agents for the Colonies, London, UK, 1937.

[100] F. R. Irvine, Woody Plants of Ghana, Oxford University Press, London, UK, 1961.

[101] J. Kerharo and J. G. Adam, La Pharmacopée Sénégalaise Traditionelle, Plantes Médicinales et Toxiques, Vigot Fréres, Paris, France, 1974.

[102] B. Nyasse, E. Nkwengoua, B. Sondengam, C. Denier, and M. Willson, "Modified berberine and protoberberines from Enantia chlorantha as potential inhibitors of Trypanosoma brucei," Pharmazie, vol. 57, no. 6, pp. 358-361, 2002.

[103] J. N. D. Trebissou, S. Beourou, E. E. C. Lohoues, H. F. Yapi, G. L. Boga, and A. J. Djaman, "In-vitro evaluation of the activity of aqueous extract of a plant coded Phyllam (Phyllanthus amarus) on two strains of Mycobacterum tuberculosis and one strain of Mycobacterum ulcerans," World Journal of Pharmaceutical Research, vol. 2, pp. 1878-1888, 2013.

[104] L. Taylor, Secrets des Plantes des Forêts Tropicales, Presse Sage, 2nd edition, 2002.

[105] A. K. Kamanzi, Medicinal plants from Cote d'Ivoire: phytochemical investigations directed by biological assays [Ph.D. thesis], University of Cocody, Abidjan, Cote d'Ivoire, 2002.

[106] O. C. Jegede, J. O. Ajanusi, A. O. Adaudi, and R. I. S. Agbede, "Anthelmintic efficacy of extracts of Spigelia anthelmia Linn on experimental Nippostrongylus braziliensis in rats," Journal of Veterinary Science, vol. 7, no. 3, pp. 229-232, 2006.

[107] M. M. Iwu, Handbook of African Medicinal Plants, CRC Press, Health \& Fitness, 2nd edition, 2014.

[108] B. Badu-Apraku and M. A. B. Fakorede, "Zea mays L," in Record from PROTA4U, M. Brink and G. Belay, Eds., PROTA (Plant Resources of Tropical Africa/Ressources Végétales de l'Afrique Tropicale), Wageningen, The Netherlands, 2006, http://www .prota4u.org/search.asp.

[109] K. M. R. Sravania, D. Sai Padmini, and S. M. Lakhsmi, "Exploration of herbal drugs used in wound healing activity," International Journal of Pharmaceutical Sciences Review and Research, vol. 13, no. 1, pp. 73-77, 2012.

[110] N. E. Sandoval-Montemayor, A. García, E. Elizondo-Treviño, E. Garza-González, L. Alvarez, and M. del Rayo CamachoCorona, "Chemical composition of hexane extract of Citrus aurantifolia and anti-Mycobacterium tuberculosis activity of some of its constituents," Molecules, vol. 17, no. 9, pp. 11173-11184, 2012.

[111] F. Spadaro, R. Costa, C. Circosta, and F. Occhiuto, "Volatile composition and biological activity of key lime Citrus aurantifolia essential oil," Natural Product Communications, vol. 7, no. 11, pp. 1523-1526, 2012.

[112] A. M. El-Sayed, S. M. Ezzat, M. M. Salama, and A. A. Sleem, "Hepatoprotective and cytotoxic activities of Delonix regia flower extracts," Pharmacognosy Journal, vol. 3, no. 19, pp. 4956, 2011.

[113] R. H. Kale, U. M. Joshi, D. P. Ambhore, and G. R. Sitaphale, "Evaluation of Delonix regia Raf. Endospermic mucilage as tablet binder," International Journal of ChemTech Research, vol. 1, no. 1, pp. 11-15, 2009. 

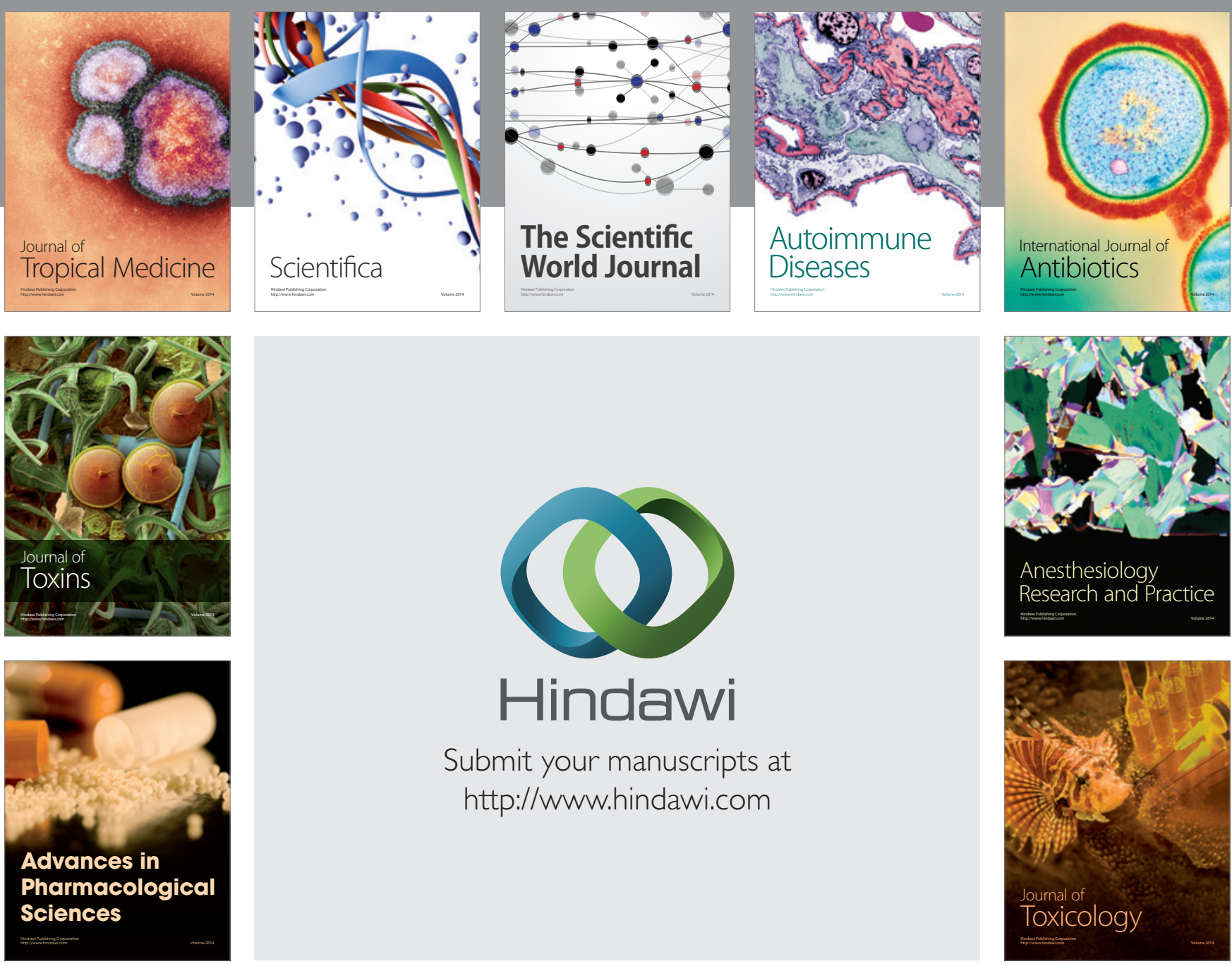

\section{Hindawi}

Submit your manuscripts at

http://www.hindawi.com
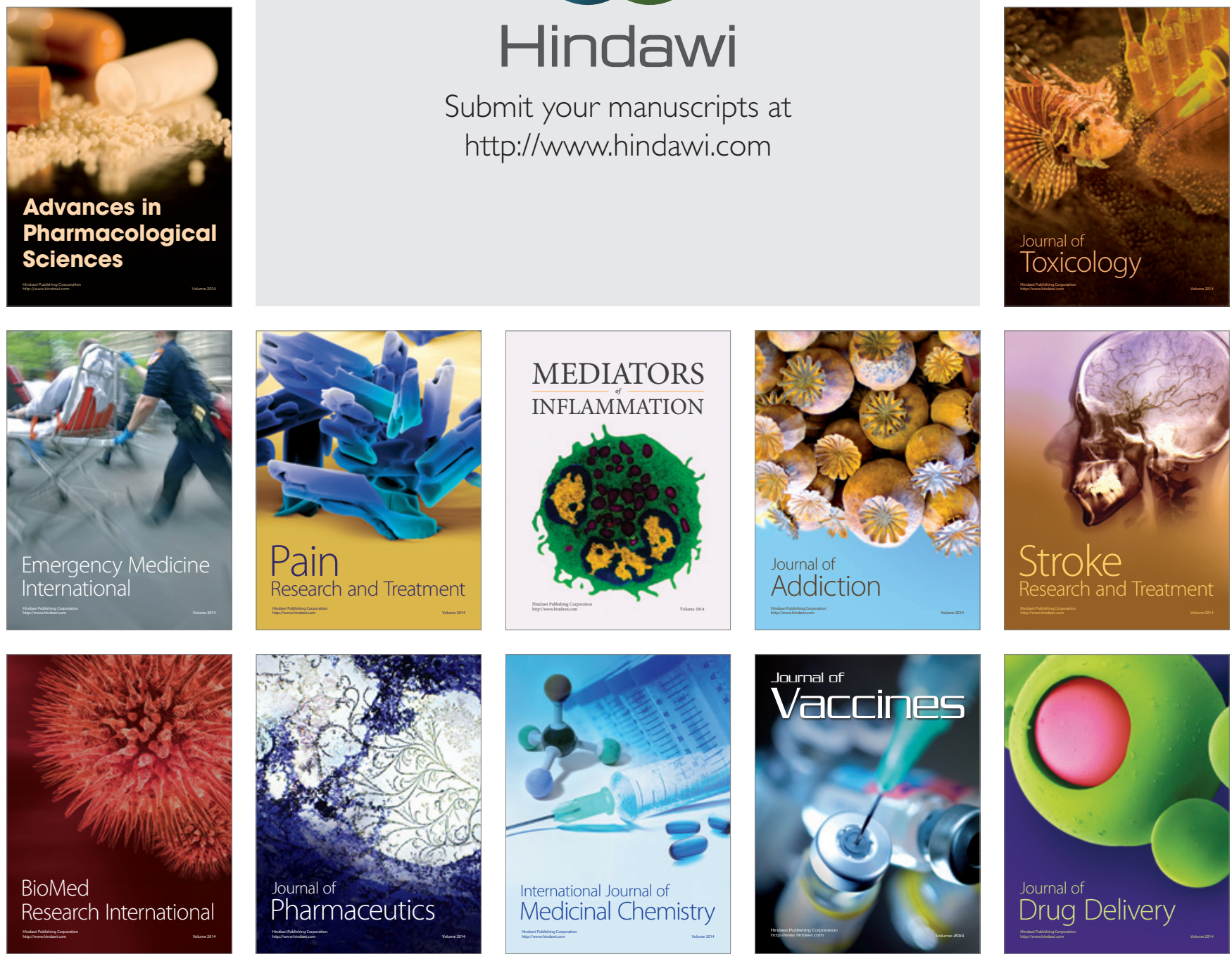